\title{
O-GIcNAcylation of High Mobility Group Box 1 (HMGB1) alters its DNA Binding and DNA Damage Processing Activities
}

Aaron T. Balana ${ }^{1}$, Anirban Mukherjee ${ }^{3}$, Harsh Nagpal ${ }^{4}$, Stuart P. Moon ${ }^{1}$, Beat Fierz ${ }^{4}$, Karen M. Vasquez ${ }^{3}$ and Matthew R. Pratt ${ }^{1,2, *}$

${ }^{1}$ Departments of Chemistry and ${ }^{2}$ Biological Sciences, University of Southern California, Los Angeles, California, 90089, United States

${ }^{3}$ Division of Pharmacology and Toxicology, College of Pharmacy, The University of Texas at Austin, Dell Pediatric Research Institute, 1400 Barbara Jordan Boulevard, Austin, TX 78723, USA.

${ }^{4}$ Laboratory of Biophysical Chemistry of Macromolecules, Institute of Chemical Sciences and Engineering, Ecole Polytechnique Fédérale de Lausanne (EPFL), 1015 Lausanne, Switzerland

${ }^{*}$ Corresponding Author: Matthew R. Pratt

Email: $\underline{\text { matthew.pratt@usc.edu }}$

\section{Table of Contents}

Supplementary Figure 1: Expressed chemical ligation generating fragment 4

Page S2

Supplementary Figure 2: Expressed chemical ligation generating fragment 5

Page S3

Supplementary Figure 3: Characterization of unmodified HMGB1

Page S4

Supplementary Figure 4: Low stoichiometry EMSA of HMGB1 with 4WJ DNA Page S5

Supplementary Figure 5: Nonlinear regression fitting of DNA circularization assay Page S6

Supplementary Figure 6: Immunoblot demonstrating siRNA-mediated depletion of HMGB1 in U2OS cell extract

Page 57

Supplementary Figure 7: Binding of HMGB1 to a 57-bp ICL-damaged DNA substrate Page S7

Supplementary Figure 8: ICL-induced mutation spectra from mutant plasmids 
a

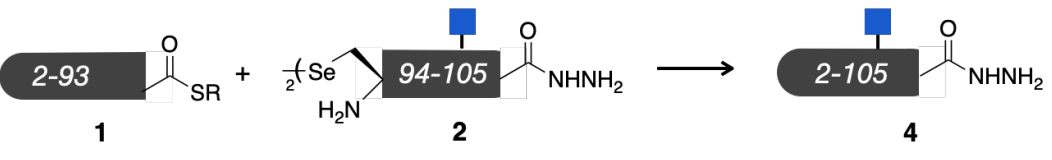

b

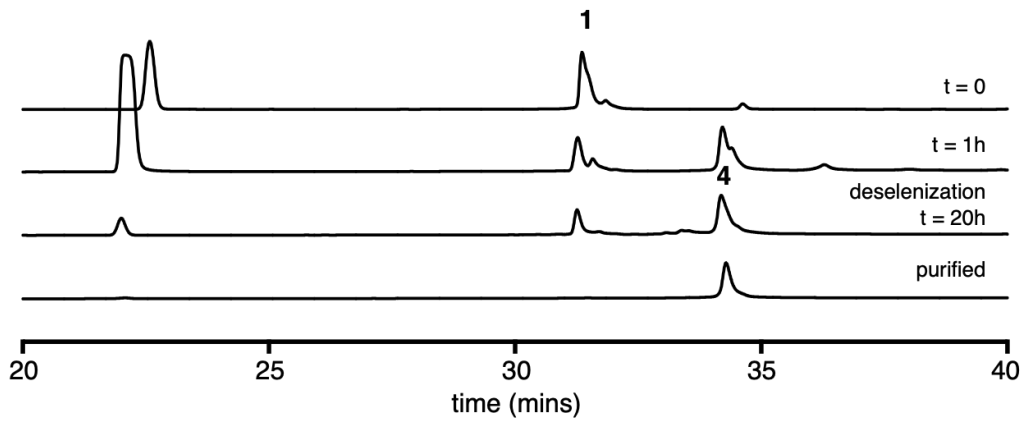

C
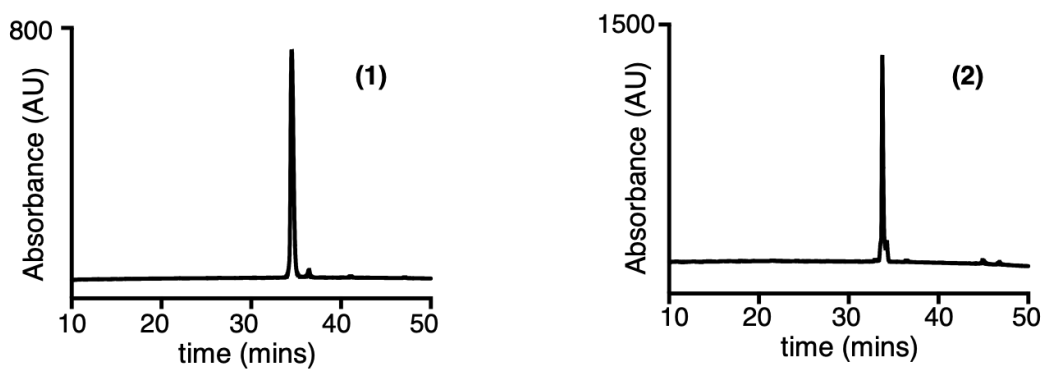

d

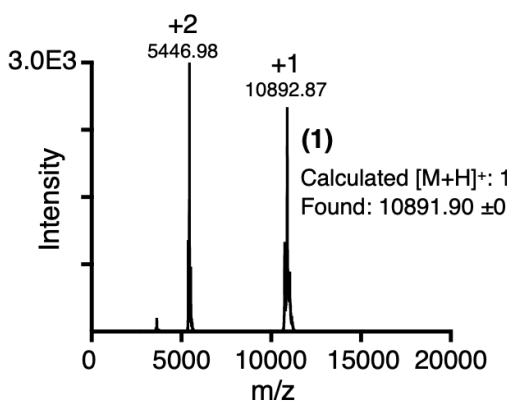

(2)
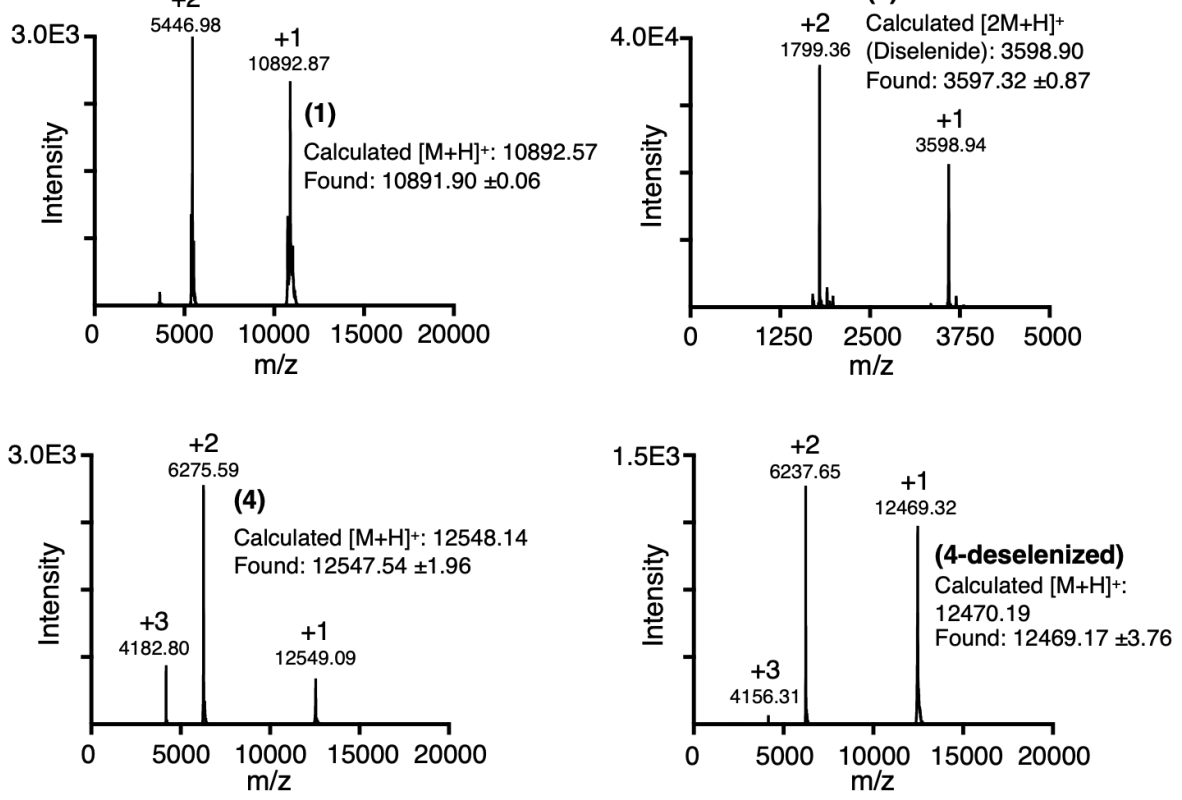

Supplementary Figure 1: Expressed chemical ligation generating fragment 4. (a) Recombinant fragment 1 and synthetic peptide 2 react to form ligation product 4. (b) RP-HPLC monitoring of ligation reaction using C4 analytical column, $0-70 \%$ solvent $B$ over 60 mins. $t=0$ trace shows 2 peaks, an early eluting species corresponding to ligation catalyst mercaptophenylacetic acid (MPAA) and a reactant peak corresponding to fragment 1 . $t=1 \mathrm{~h}$ trace shows formation of ligation product. After buffer exchange to remove MPAA and treatment with excess TCEP, removal of selenol is completed in the $t=20 \mathrm{~h}$ trace. Fragment 4 was purified and submitted to the succeeding step. Identities of peaks labeled 1 and $\mathbf{4}$ were confirmed by collecting the fraction and injecting directly on an ESI-MS. Identities of the other smaller peaks were not determined. (c) Analytical RP-HPLC traces of purified reactants on a C4 column (for fragment 1) or C18 column (for fragment 2) using a gradient of $0-70 \%$ solvent B over 60 mins. (d) MALDI-MS characterization of reactants and intermediates. 
a

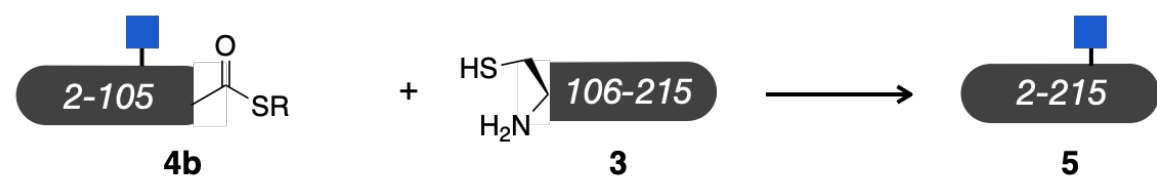

b

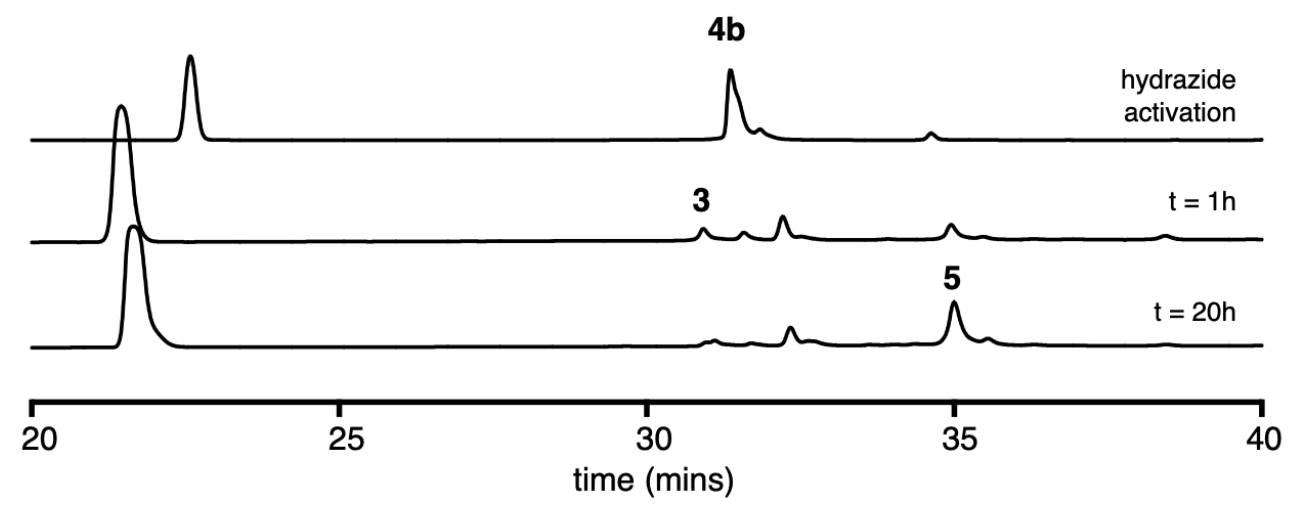

C

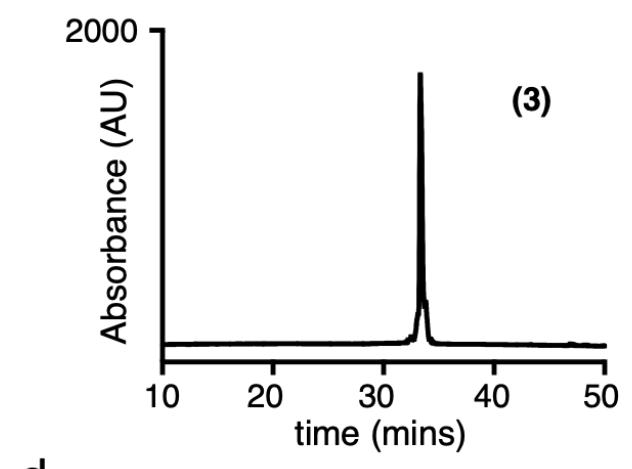

d
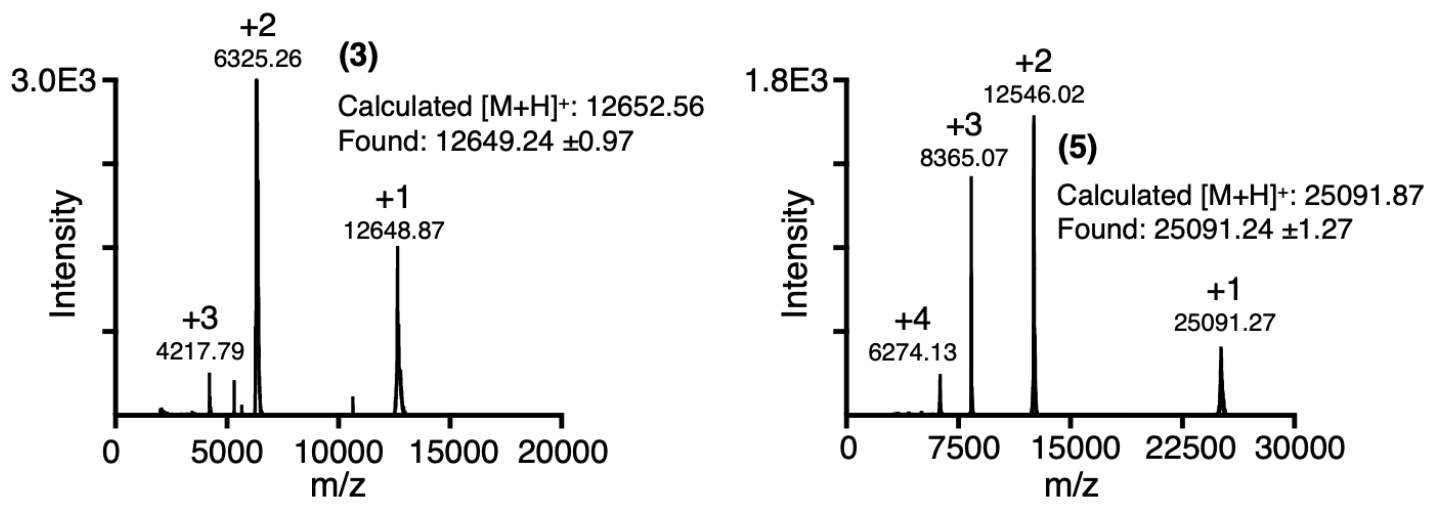

Supplementary Figure 2: Expressed chemical ligation generating fragment 5. (a) Ligation product 4 was subjected to hydrazine activation and thioesterification to generate $\mathbf{4 b}$ which was reacted with recombinant fragment 3 react to form ligation product 5. (b) RP-HPLC using C4 analytical column, 0-70\% solvent B over 60 mins. Hydrazide activation trace shows MPAA peak and thioester $\mathbf{4 b} . \mathrm{t}=1 \mathrm{~h}$ trace shows addition of fragment $\mathbf{3}$ formation of ligation product 5. Product formation was complete in the $\mathrm{t}=20 \mathrm{~h}$ trace. Product $\mathbf{5}$ was purified and subjected to O-acetate deprotection to generate HMGB1(gS100). Identities of peaks labeled $\mathbf{4 b}, \mathbf{3}$ and $\mathbf{5}$ were confirmed by collecting the fraction and injecting directly on an ESI-MS. Identities of the other smaller peaks were not determined. (c) Analytical RP-HPLC trace for fragment 3 using a C4 column on a gradient of $0-70 \%$ B over 60 mins. (d) MALDI-MS characterization of reactant 3 and intermediate 5. 
a

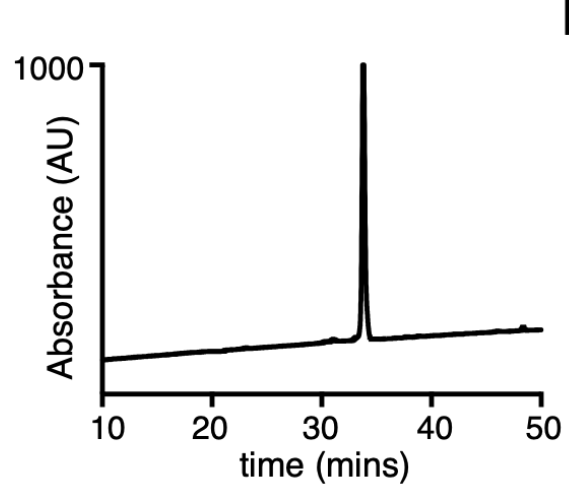

C

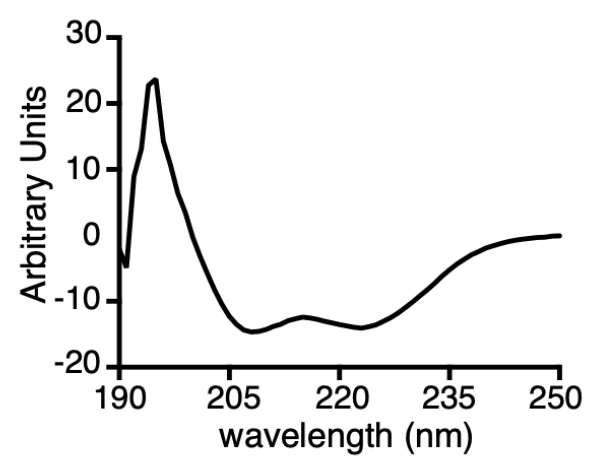

b
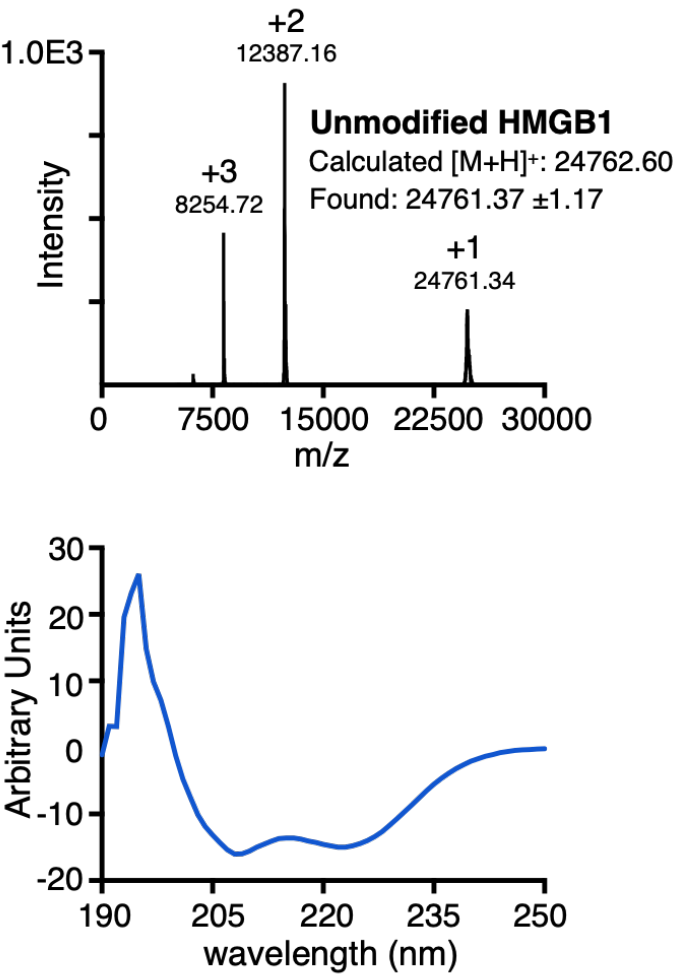

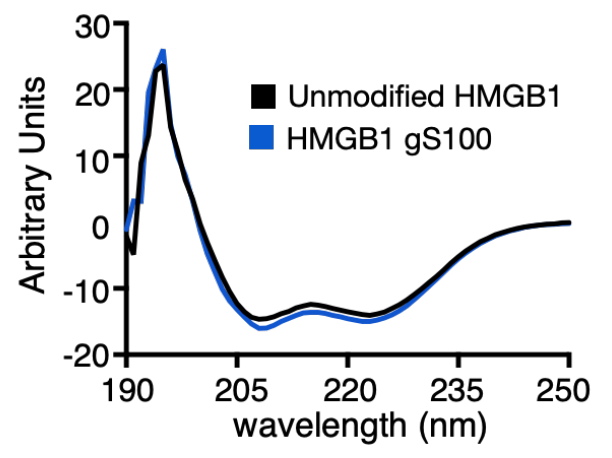

Supplementary Figure 3: Characterization of unmodified HMGB1. (a) Analytical RP-HPLC trace of recombinant, unmodified HMGB1 purified from an intein fusion construct using a C4 column, $0-70 \%$ solvent B over 60 mins. (b) MALDI-MS of recombinant, unmodified HMGB1. (c) Top, circular dichroism profiles of unmodified HMGB1 (black, left) and HMGB1(gS100) (blue, left). Overlaid CD spectra are shown in the bottom panel. 
a

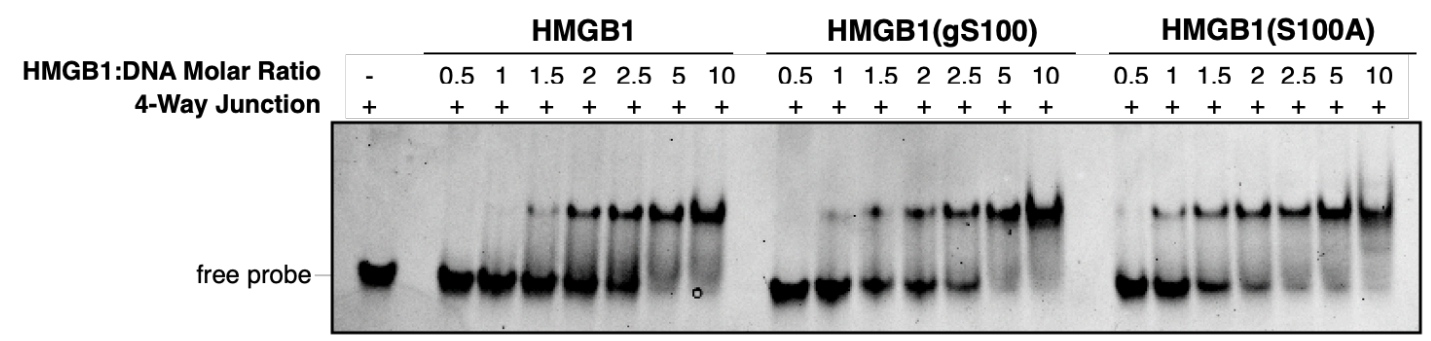

b
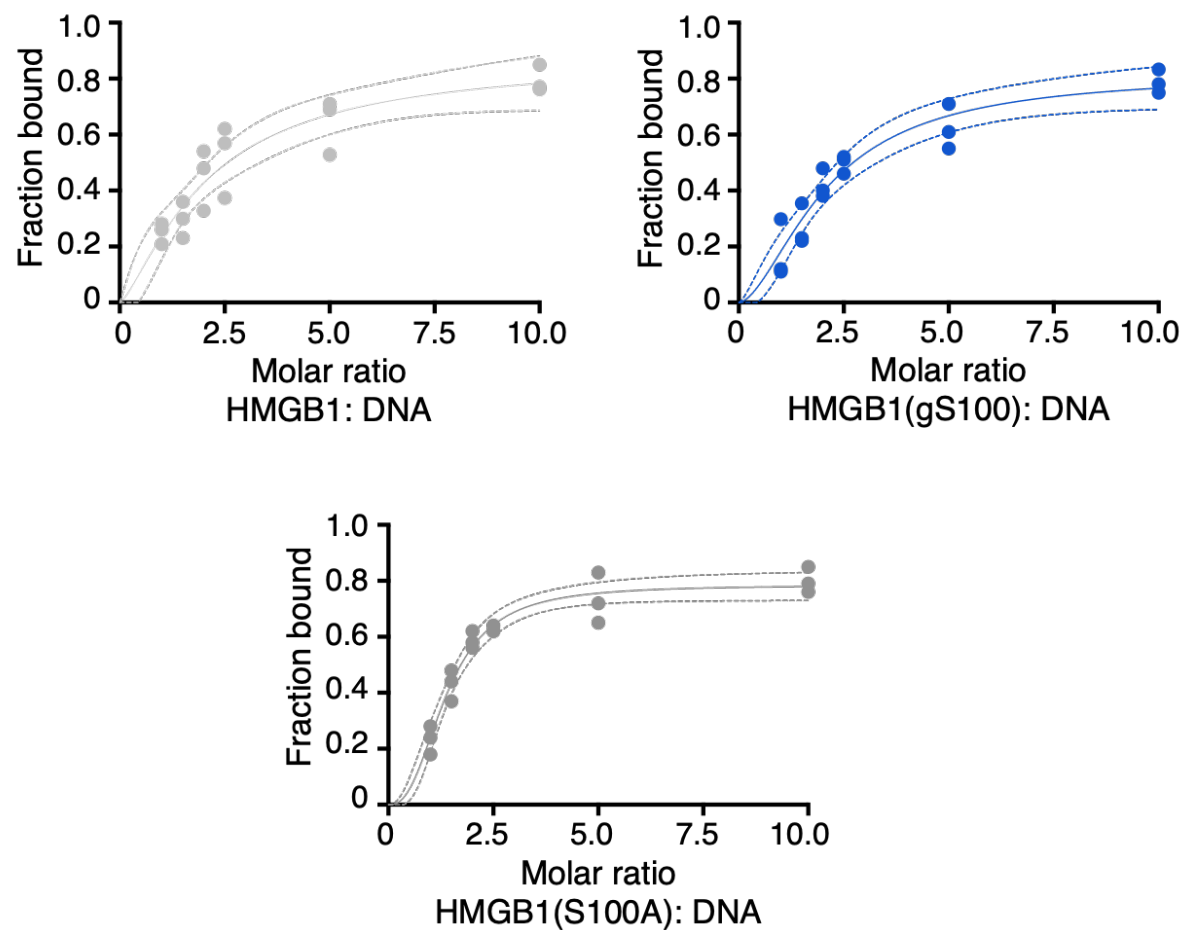

C

\begin{tabular}{cccc}
\hline Comparison of fits & $\mathbf{R}^{\mathbf{2}}$ & $\begin{array}{c}\text { Binding affinity } \\
\text { (molar ratio) }\end{array}$ & P values \\
\hline HMGB1 & 0.8538 & 2.081 & \\
HMGB1(gS100) & 0.9126 & 2.099 & 0.9784 (vs HMGB1) \\
HMGB1(S100A) & 0.9425 & 1.384 & $\begin{array}{c}0.0199 \text { (vs HMGB1) } \\
0.0011 \text { (vs gS100) }\end{array}$ \\
\hline
\end{tabular}

Supplementary Figure 4: Low stoichiometry EMSA of HMGB1 with 4WJ DNA. (a) Representative EMSA for fourway junction DNA (100 nM) incubated with indicated amounts of HMGB1, HMGB1(gS100), or HMGB1(S100A) at low equivalents. (b) To calculate the fraction of DNA bound at given molar ratio, densitometric measurements for the shifted bands corresponding to bound DNA were divided by the combined signal from shifted and unshifted bands. Fraction bound were plotted against molar ratios of HMGB1:DNA and a saturation binding nonlinear regression fit was calculated using results from $\mathrm{N}=3$ replicates per HMGB1 variant. Solid line represents best-fit curve while dotted lines indicate $95 \%$ confidence interval of the curve. (c) Summary of regression fitting parameters including calculated binding affinities expressed as molar ratios. $\mathrm{P}$ values for comparison of binding affinities were calculated using pairwise extra-sum-of-squares $\mathrm{F}$ test comparison of nested models. 
a
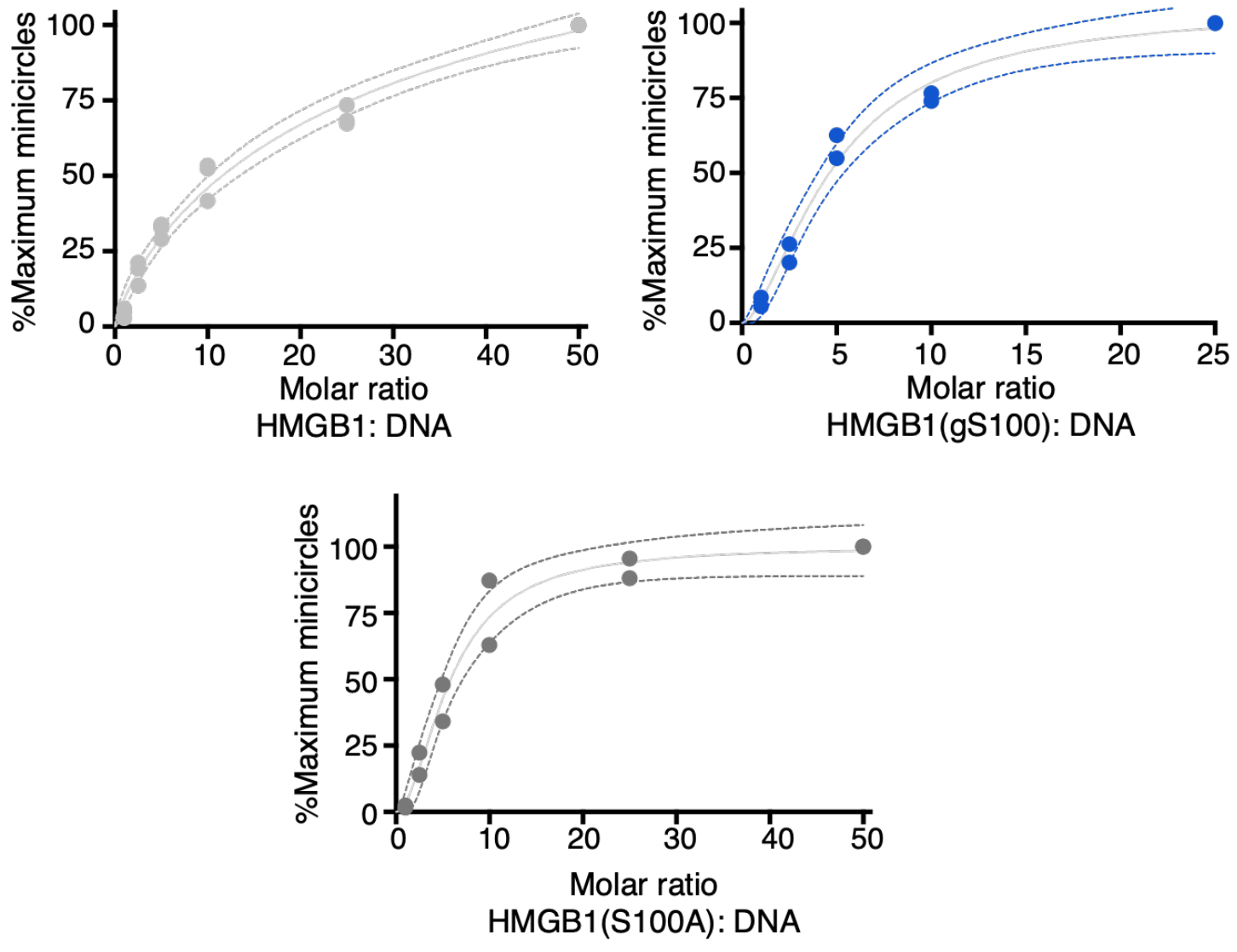

b

\begin{tabular}{cccccc}
\hline Comparison of fits & $\mathbf{R}^{\mathbf{2}}$ & $\begin{array}{c}\text { Half-Max } \\
\text { Ratio }\end{array}$ & $\begin{array}{c}\text { P values } \\
\text { (Half-Max Ratio) }\end{array}$ & h (Hill coefficient) & P values (h) \\
\hline HMGB1 & 0.9816 & 33.54 & & 0.8146 & \\
HMGB1(gS100) & 0.9483 & 4.903 & 0.0002 (vs HMGB1) & 1.632 & 0.0022 (vs HMGB1) \\
HMGB1(S100A) & 0.9710 & 5.869 & $\begin{array}{c}0.0001(\text { vs HMGB1) } \\
0.3875(\text { vs gS100) }\end{array}$ & 1.888 & $\begin{array}{c}0.0007 \text { (vs HMGB1) } \\
0.5663 \text { (vs gS100) }\end{array}$ \\
\hline
\end{tabular}

Supplementary Figure 5: Nonlinear regression fitting of DNA circularization assay. Densitometric measurements for the bands corresponding to DNA minicircles were normalized to the maximum minicircles signal for each experiment to obtain \%Maximum minicircles. \%Maximum minicircles were plotted against molar ratios of HMGB1:DNA and a saturation binding (with Hill slope) nonlinear regression fit was calculated using results from $\mathrm{N}>2$ replicates per HMGB1 variant. For the plots in (a), dots correspond to individual normalized \%Maximum minicircles, solid lines correspond to best-fit line, and dotted lines correspond to boundaries of the $95 \% \mathrm{Cl}$ of the best-fit lines. (b) Summary of binding parameters obtained from nonlinear regression fitting. $P$ values for comparison of half-max ratios and $\mathrm{h}$ coefficients were calculated using pairwise extra-sum-of-squares $\mathrm{F}$ test comparison of nested models. 


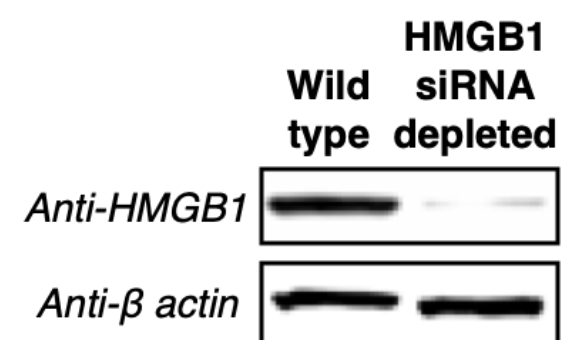

Supplementary Figure 6: Immunoblot demonstrating siRNA-mediated depletion of HMGB1 in U2OS cell extract.

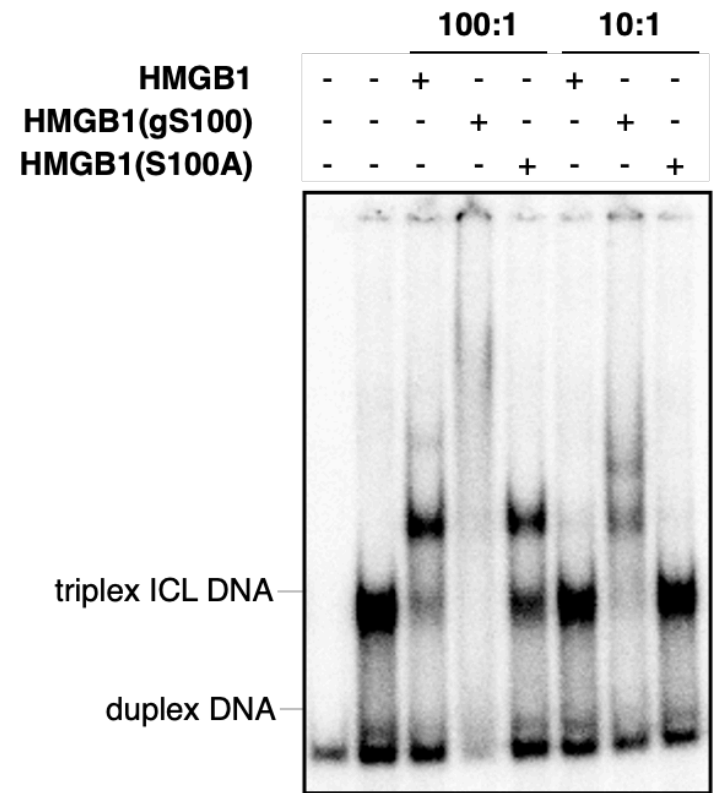

Supplementary Figure 7: Binding of HMGB1 variants to a 57-bp ICL-damaged DNA substrate. Psoralen triplexforming oligos were added to radiolabeled 57-bp DNA and irradiated with UVA to form triplex ICL DNA (1 nM). Ten or 100 molar equivalents of each HMGB1 variant were used during complex formation. Complexes were resolved by native polyacrylamide gel electrophoresis and visualized using a phosphorimager. 


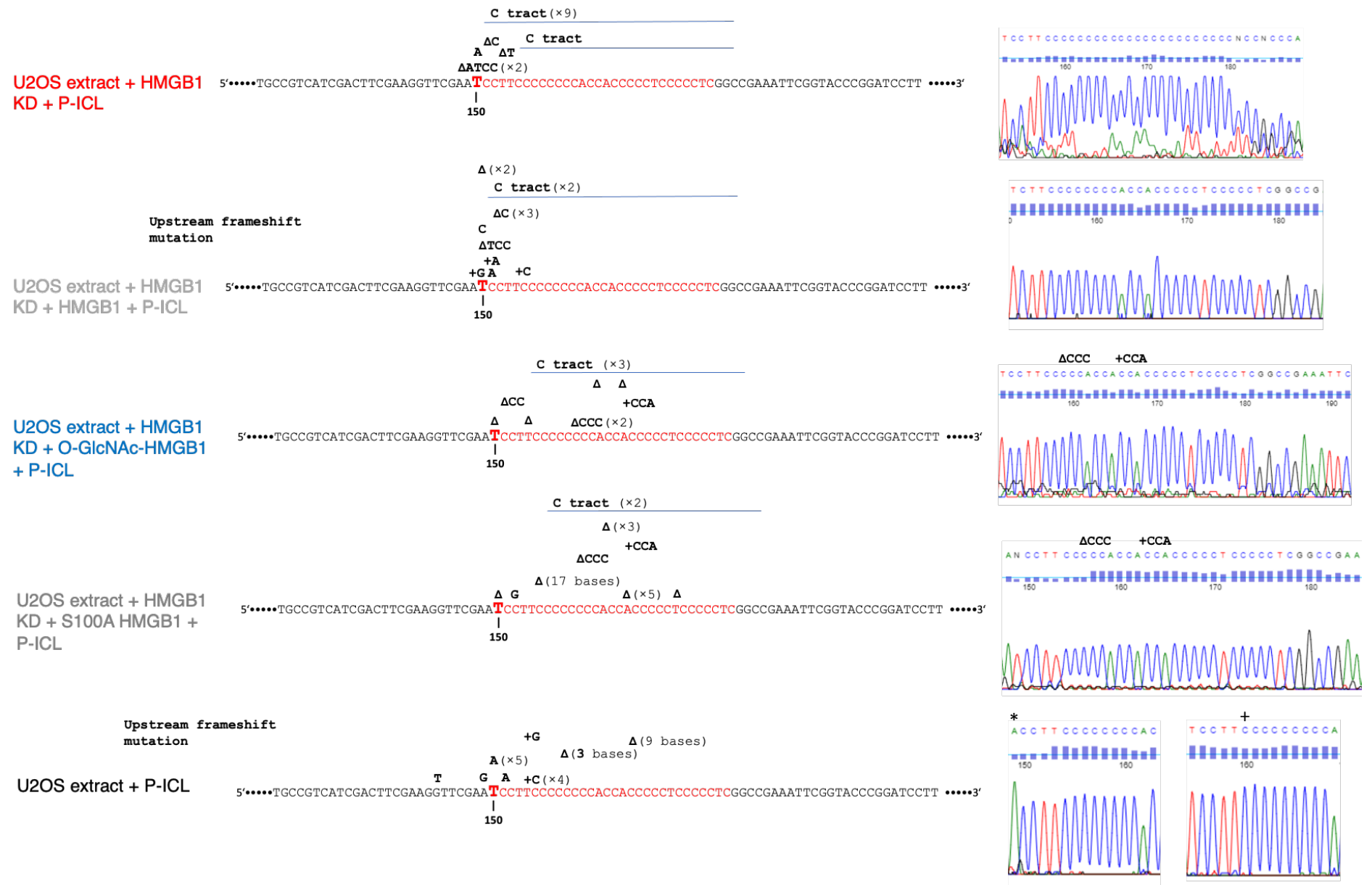

Supplementary Figure 8: ICL-induced mutation spectra from mutant plasmids generated in wild-type, or HMGB1depleted U2OS without or with HMGB1, HMGB1(gS100) or HMGB1(S100A) addback. Shown in red is the triplexforming oligonucleotide targeting site. The ICL-forming thymine $(T)$ is identified as residue 150 . The base substitutions are indicated above the original sequence at the respective positions, insertions are indicated by $+\mathrm{N}$, deletions are indicated with triangles, and C-tracts are labeled accordingly. The numbers within parenthesis indicate the number of times a mutation occurred in that specific residue or region. Representative chromatograms are also shown on the right. 
General. All solvents and reagents were purchased from commercial sources and used without any further purification. All aqueous solutions were prepared using ultrapure laboratory grade water (deionized, filtered, and sterilized) obtained from an in-house water purification system. Growth media were prepared, sterilized, stored, and used according to the instructions of the manufacturer. Antibiotics were prepared as stock solutions at a concentration of $1000 \times(100 \mathrm{mg} / \mathrm{mL}$ ampicillin sodium salt $)$ and stored at $-20{ }^{\circ} \mathrm{C}$. All bacterial growth media and cultures were handled using sterile conditions under an open flame. Protein concentrations were determined by the Pierce BCA Protein Assay Kit (Thermo Fisher Scientific). Reversed-phase high-performance liquid chromatography (RP-HPLC) was performed using an Agilent Technologies 1200 Series HPLC instruments with a diode array detector with semi-preparative and analytical C4 or C18 columns from Higgins Analytical. The following reversed-phase chromatography solvents were used: Solvent $\mathrm{A}, 0.1 \%$ TFA in $\mathrm{H}_{2} \mathrm{O}$; solvent $\mathrm{B}, 0.1 \%$ TFA and $90 \%$ ACN in $\mathrm{H}_{2} \mathrm{O}$. Mass spectra were acquired on an API 150EX LC/MS-MS system (Applied Biosystems/MDS SCIEX) or a Daltonics Autoflex MALDI-TOF (Bruker) using a-cyano-4-hydroxycinnamic acid (HCCA) as matrix. Oligonucleotides were ordered from commercial sources (IDT DNA) with the standard desalting and purification methods. Statistical testing was performed using GraphPad Prism 8.

Molecular cloning and plasmids. Constructs for mammalian expression were derived from the pcDNA3.1FLAG-HMGB1 vector, a gift from Yasuhiko Kawakami (Addgene plasmid \#31609; RRID:Addgene_31609). This expression vector was used as is as the wild-type variant. S100A, S107A, and double mutants of the FLAGHMGB1 construct were prepared using QuikChange Site-Directed mutagenesis kit (Agilent) following manufacturer protocol. An HA-tagged HMGB1 mammalian overexpression vector was constructed using standard restriction digestion-based cloning methods. The insert was amplified with PCR overhang to append a 5' Agel cut site and HA-tag and 3' Hindlll cut site. This insert was digested and ligated back into the same pcDNA3.1 backbone of the FLAG-HMGB1 construct using T7 ligase. Sequences were confirmed via Sanger sequencing (Laragen) using CMV primers.

Codon-optimized HMGB1 gene for E. coli expression was designed with and synthesized by Genscript. Inserts corresponding to full-length protein, 1-93, and 106-215 were amplified using overhang PCR to attach 5' Ndel and 3' Bpu10I cut sites using KOD HotStart Master Mix (EMD Millipore). Inserts were digested with restriction enzymes (NEB), and ligated with T4 DNA ligase (NEB) onto a pTXB1 vector that was digested and treated with calf intestine phosphatase. The pTXB1 vector allows fusion of a C-terminal intein-6xHis tag for affinity purification. DNA ligations were transformed onto high efficiency DH5a competent cells (NEB) and selected on ampicillin plates. Correct clones bearing the intended inserts were determined by restriction enzyme digestion and Sanger sequencing (Laragen) using T7 and T7-reverse primers.

Expression and purification of GalT(Y289L). pET23a GalT Y289L plasmid (P. Qasba, National Cancer Institute) was transformed into BL21 E. coli. Three $500 \mathrm{~mL}$ Terrific Broth cultures (EMD Millipore, total $1.5 \mathrm{~L}$ media) with $100 \mathrm{ug} / \mathrm{mL}$ ampicillin was inoculated starter culture grown overnight at $37^{\circ} \mathrm{C}$. The TB cultures were grown at $37^{\circ} \mathrm{C}$ to an OD of 0.60 and induced with $1 \mathrm{mM}$ isopropyl $\beta-D$-1-thiogalacto-pyranoside (Carbosynth) for $4 \mathrm{~h}$ at $37^{\circ} \mathrm{C}$. Cells were harvested by centrifugation for 15 minutes at $6,000 \mathrm{~g}, 4^{\circ} \mathrm{C}$. Cell pellets were resuspended in $30 \mathrm{~mL}$ of resuspension buffer ( $25 \%$ sucrose w/v in Dulbecco's Phosphate Buffered Saline). The resuspended cells were divided into $6 \times 5 \mathrm{~mL}$ fractions and each fraction was sonicated (30 s pulse, $30 \mathrm{~s}$ rest, 12 min total) on ice. The lysates were pooled and diluted to $500 \mathrm{~mL}$ with ice-cold suspension buffer. The protein in inclusion bodies were harvested by centrifugation $\left(20 \mathrm{~min}, 20,000 \mathrm{~g}, 4^{\circ} \mathrm{C}\right)$. Inclusion bodies were washed 8 times by repeated cycles of addition of $200 \mathrm{~mL}$ suspension buffer, vigorous vortexing, and centrifugation. Washing was deemed complete when the pellet turned white. Inclusion bodies were then washed one last time with $200 \mathrm{~mL}$ cold wash buffer (10 mM phosphate, $\mathrm{pH} 7.0)$ and harvested by centrifugation. The protein was released from inclusion bodies by first resuspending in $14 \mathrm{~mL}$ of cold $\mathrm{H}_{2} \mathrm{O}$ followed by the addition of solid guanidine $\mathrm{HCl}$ and $\mathrm{Na}_{2} \mathrm{SO}_{3}$ (final concentrations of $5 \mathrm{M} \mathrm{GnHCl}$ and $300 \mathrm{mM} \mathrm{Na}_{2} \mathrm{SO}_{3}$ ). The solution was vortexed vigorously and diluted to $25 \mathrm{~mL}$ with cold $\mathrm{H}_{2} \mathrm{O}$. Freshly made 2-nitro-5-sulfothio-benzonate (NTSB) solution (50 mM DTNB, $1 \mathrm{M}$ $\mathrm{Na}_{2} \mathrm{SO}_{3}$ in water $\mathrm{pH}$ 8.0) was then added with vigorous vortex mixing to sulfonate free thiols. The solution gradually changed color from dark orange to pale yellow, suggesting completeness of the reaction. The protein was precipitated with cold $\mathrm{H}_{2} \mathrm{O}(250 \mathrm{~mL})$ at which point the sulfonated protein precipitated and was centrifuged immediately (30 min, $10,000 \mathrm{~g}, 4^{\circ} \mathrm{C}$ ). The protein pellet was washed thrice with cycles of resuspension in cold water and centrifugation. Finally, the protein pellet was resuspended in $14 \mathrm{~mL}$ of cold $\mathrm{H}_{2} \mathrm{O}$ and solid guanidine 
$\mathrm{HCl}$ was added. The solution was vortexed to resuspend completely and centrifuged at $5,000 \mathrm{~g}$ for $15 \mathrm{mins}$ at room temperature. Protein concentration was adjusted to $1 \mathrm{mg} / \mathrm{mL}$ with a $5 \mathrm{M} \mathrm{GuHCl}$ solution so that the OD at $275 \mathrm{~nm}$ is around 2.0. This solution was slowly diluted 10 -fold by the addition of ice-cold refolding buffer ( $5 \mathrm{mM}$ EDTA, $4 \mathrm{mM}$ cysteamine, $2 \mathrm{mM}$ cystamine, $100 \mathrm{mM}$ Tris base, $\mathrm{pH}$ 8.0) with gentle, continuous swirling. Refolding was allowed to proceed for $48 \mathrm{~h}$ at $4^{\circ} \mathrm{C}$ without agitation. Refolded protein was dialyzed twice into cold, ultrapure water for 24 hours each. Precipitated protein was removed by centrifugation $\left(15,000 \mathrm{~g}, 15 \mathrm{mins}\right.$ at $\left.4^{\circ} \mathrm{C}\right)$. Protein was concentrated first with pressure concentrators using a $10 \mathrm{~K}$ ultracel regenerated cellulose filter, and finally with Amicon 10kDa MWCO centrifugal filters. Protein was buffer exchanged to $10 \mathrm{mM}$ Tris base, pH 8.0 buffer, and final protein concentration was adjusted to $1 \mathrm{mg} / \mathrm{mL}$. Enzyme purity was assessed by SDS-PAGE and activity through chemoenzymatic labeling and fluorescence detection.

Chemoenzymatic pulldown of endogenously O-GIcNAc modified proteins. Human non-small cell lung carcinoma, H1299 cells (ATCC) were grown in RPMI media supplemented with $10 \% \mathrm{FBS}$, at $37^{\circ} \mathrm{C}$ under $5 \%$ $\mathrm{CO}_{2}$. Cells at $90 \%$ confluency were collected by trypsinization, resuspension in Dulbecco's Phosphate Buffered Saline (DPBS, Corning), and centrifugation. Cell pellets were washed twice with DPBS. Cell pellets were initially resuspended in $0.05 \%$ SDS buffer $\left(0.05 \%\right.$ SDS, $5 \mathrm{mM} \mathrm{MgCl}_{2}, 10 \mathrm{mM}$ triethanolamine, pH 7.4) onto which Benzonase (Sigma) was added to reduce viscosity. After 30 minutes incubation on ice, $4 \%$ SDS buffer (4\% SDS, $150 \mathrm{mM} \mathrm{NaCl}, 50 \mathrm{mM}$ TEA, $\mathrm{pH}$ 7.4) was added. The solution was bath sonicated, centrifuged, and the supernatant was collected. Protein concentration was determined, and the lysate was diluted to $1 \mathrm{mg} / \mathrm{mL}$ in $1 \%$ SDS chemoenzymatic transfer buffer (1\% SDS, $20 \mathrm{mM} \mathrm{HEPES,} \mathrm{pH} \mathrm{7.9).} \mathrm{Proteins} \mathrm{were} \mathrm{then} \mathrm{precipitated} \mathrm{through}$ methanol chloroform precipitation, first by the addition of $3 \mathrm{X}$ methanol, $0.75 \mathrm{X}$ chloroform, and $2 \mathrm{X}$ water. The suspension was centrifuged, and the top layer was carefully removed, after which the protein pellet at the interface was washed with $2.25 \mathrm{X}$ methanol. Following centrifugation, the pellet was dried and then subjected to chemoenzymatic transfer.

The protein precipitate was resuspended in 1\% SDS chemoenzymatic transfer buffer. Concentrations were determined using BCA assay and $1 \mathrm{mg}$ of total protein was used during the chemoenzymatic labeling. To set up the transfer, protein concentrations were adjusted to $2.5 \mathrm{mg} / \mathrm{mL}$ by diluting in $1 \%$ SDS chemoenzymatic transfer buffer to a final volume of $400 \mathrm{uL}$. The following reagents were added then added: $390 \mu \mathrm{L}$ of $\mathrm{H}_{2} \mathrm{O}, 800 \mu \mathrm{L}$ of labeling buffer (2.5X: 5\%NP-40, $125 \mathrm{mM} \mathrm{NaCl}, 50 \mathrm{mM}$ HEPES, pH 7.9), $110 \mu \mathrm{L}$ of $100 \mathrm{mM} \mathrm{MnCl}, 150 \mu \mathrm{L}$ of UDP-GalNAz (0.5 mM in $10 \mathrm{mM}$ HEPES, pH 7.9). After vortexing, $112.5 \mu \mathrm{L}$ of GalT(Y289L) enzyme were added and the reactions were mixed by swirling with the pipet tip gently. Reactions were incubated for $4{ }^{\circ} \mathrm{C}$ without agitation. After 20 hours, $185 \mu \mathrm{L}$ of $600 \mathrm{mM}$ iodoacetamide in $\mathrm{H}_{2} \mathrm{O}$ were added to each reaction (50 mM final concentration) and reactions were incubated in the dark at room temperature for 30 min in order to cap reactive cysteines. Proteins were then precipitated from the mixture by methanol-chloroform precipitation.

Protein pellets were air dried and resuspended first in 4\% SDS TEA buffer (4\% SDS, $600 \mathrm{mM} \mathrm{NaCl,} 200 \mathrm{mM}$ triethanolamine, $\mathrm{pH} 7.4$ ) at $4 \mathrm{mg} / \mathrm{mL}$ protein concentration. Inputs were prepared by taking $50 \mu \mathrm{g}$ of protein and adding the same volume of $2 \mathrm{X}$ loading buffer ( $20 \%$ glycerol, $0.2 \%$ bromophenol blue, $1.4 \% \beta$-mercaptoethanol) to a final protein concentration of $2 \mathrm{mg} / \mathrm{mL}$. The protein concentrations were diluted with water to $1 \mathrm{mg} / \mathrm{mL}$ protein at $1 \%$ final SDS concentration. Freshly made CuAAC master mix were then added so that the final reactions contained $100 \mu \mathrm{M}$ alkyne-azo-biotin, $1 \mathrm{mM}$ TCEP, $100 \mu \mathrm{M}$ TBTA, and $1 \mathrm{mM} \mathrm{CuSO}$ :5 $\mathrm{H}_{2} \mathrm{O}$. After $1 \mathrm{~h}$ in the dark, EDTA was added (5 $\mathrm{mM}$ final concentration) to quench the reaction, and the proteins were again precipitated by methanol-chloroform precipitation.

For the biotin pulldown of O-GlcNAcylated proteins, pellets were dissolved in $4 \%$ SDS TEA buffer and resuspended completely by boiling and bath sonication. The SDS and protein concentrations were adjusted to $0.2 \%$ and $0.5 \mathrm{mg} / \mathrm{mL}$ respectively, and $50 \mu \mathrm{L}$ Neutravidin beads (ThermoFisher Scientific) pre-washed in $0.2 \%$ SDS TEA buffer were added. Beads were subjected to full rotation for $1.5 \mathrm{~h}$, collected, then washed with $30 \mathrm{~mL}$ of wash buffer (1\% SDS in PBS, pH 7.4) using a vacuum manifold. Beads were transferred to dolphin-nosed tubes, into which $100 \mu \mathrm{L}$ of elution buffer (25 mM sodium dithionite, 1\% SDS in PBS, pH 7.4) were added. 
Proteins were eluted at room temperature for $30 \mathrm{~min}$. Elutions were collected by spinning down the beads ( $2000 \mathrm{~g}$ for $3 \mathrm{~min}$ ) and transferring the supernatant into a fresh tube. Addition of elution buffer was repeated one more time, and elutions were pooled. Eluted proteins were precipitated by the addition of $4 \mathrm{X}$ volume of cold methanol and incubation at $-20^{\circ} \mathrm{C}$ over 2 hours. Enriched proteins were collected, the supernatant was removed, and the pellets were air-dried. Enriched proteins were resuspended in $15 \mu \mathrm{L}$ of $4 \%$ SDS TEA buffer and $15 \mu \mathrm{L}$ of $2 \mathrm{X}$ loading buffer, boiled, and stored for SDS-PAGE and immunoblotting.

FLAG- and HA- mutant chemoenzymatic pulldown. $\mathrm{H} 1299$ cells cells grown at $80 \%$ confluency were contransfected with $18 \mu \mathrm{g}$ pcDNA3.1 FLAG-HMGB1 (wild-type or mutant) and $2 \mu \mathrm{g}$ pcDNA3.1 HA-HMGB1 (wildtype) DNA using Lipofectamine 2000 (Invitrogen) according to manufacturer's standard protocol. The DNA amounts were previously optimized to result in comparable signal production during the immunoblotting step. Cells were collected by trypsinization 16 hours post-transfection and subjected to the same chemoenzymatic pulldown experiment described above. During SDS-PAGE, $10 \mu \mathrm{g}$ of inputs were loaded while half of the volume of the pulldown sample were loaded per well.

For imaging of the immunoblots, both FLAG- and HA-blots were imaged simultaneously to enable quantification and normalization. Protein levels were quantified using the signal volume tool on the ChemiDoc Image Lab software. Normalized IP signals were calculated by dividing the densitometric value of the pulldown band by the input band for the same sample. To compare normalized IP values, an average of the normalized IP values for the HA (wild-type) experiments was calculated and used as baseline. The normalized IP values of the mutant experiments were then divided by this average to obtain the pulldown efficiency ratio shown in Figure 1c.

SDS-PAGE and Western Blotting. Gel samples were bath sonicated and boiled for 10 min prior to running SDS-PAGE on precast 4-20\% polyacrylamide gels (BioRad) with Tris-Glycine running buffer (BioRad). Separated proteins were transferred on PVDF membranes using a semi-dry transfer apparatus at 20V for 1 hour. After transfer, membranes were blocked for $1 \mathrm{~h}$ at room temperature using OneBlock Western-FL Blocking Buffer (Genesee Scientific). Primary antibody incubation was performed by the addition of antibodies diluted in OneBlock buffer (Anti-HMGB1 1:5,000 CST 3935; Anti-Beta Actin 1:10,000 Sigma A2066; Anti-Nup62 1:5,000 BD Bioscience 610497; Anti-FLAG 1:1,000 CST 2368; Anti-HA 1:1,000 CST 3724). Primary antibody was incubated at $4{ }^{\circ} \mathrm{C}$ overnight with rocking. Antibody solution was removed and membranes were washed with TBST (137 mM NaCl, $20 \mathrm{mM}$ Tris, 0.1\% Tween-20, pH 7.6, Cell Signaling Technology) for 10 mins, repeated three times. HRP-conjugated anti-rabbit or anti-mouse secondary antibodies $(1: 10,000$, Jackson ImmunoResearch) in OneBlock buffer were added to the membranes followed by incubation at room temperature for 1 hour with rocking. Membranes were washed with TBST three times for 10 minutes each. Membranes were then developed with Western ECL Substrates (Biorad) and imaged using a ChemiDoc XRS+ Imager (Bio-Rad). Densitometric analyses were performed using BioRad Image Lab software. For membranes that were re-probed by consecutive addition of primary antibodies (from orthogonal source organisms), $1 \%$ sodium azide $\mathrm{w} / \mathrm{v}$ in OneBlock buffer was added during the blocking and primary antibody incubation steps to deactivate any bound HRP-conjugated secondary antibodies.

Generation of HMGB1 1-93 Thioester (1). BL21(DE3) (EMD Millipore) cells were transformed with HMGB1(193)AvaE-6xHis fusion plasmid DNA using heat shock method and transformants were selected on ampicillin plates. A starter culture was grown overnight at $37^{\circ} \mathrm{C}$ overnight from a single colony. $3 \mathrm{~L}$ of terrific broth were then inoculated with the overnight culture and grown to an $\mathrm{OD}_{600}$ of $0.6-0.8$ at $37^{\circ} \mathrm{C}$ while being shaken at 250 $\mathrm{rpm}$. Protein expression was induced by the addition of IPTG at a final concentration of $0.5 \mathrm{mM}$. Induction was allowed to proceed overnight at $16^{\circ} \mathrm{C}$ with shaking at $250 \mathrm{rpm}$. Cells were harvested at $6,000 \mathrm{~g}$, and resulting pellets were resuspended in lysis buffer $\left(20 \mathrm{mM} \mathrm{NaH}_{2} \mathrm{PO}_{4}, 250 \mathrm{mM} \mathrm{NaCl}, 1 \mathrm{mM}\right.$ TCEP, $5 \mathrm{mM}$ imidazole, and 2 mM PMSF, pH 7.5). The slurry was tip sonicated on ice (75\% amplitude, 30s on, 30s off, total of 6 minutes) and clarified by centrifugation $\left(7000 \mathrm{~g}\right.$ for $60 \mathrm{~min}$ at $4{ }^{\circ} \mathrm{C}$ ). Supernatants were loaded onto Co-NTA agarose beads (Genessee Scientific) and washed extensively (20 mM NaH $\mathrm{PO}_{4}, 250 \mathrm{mM} \mathrm{NaCl}, 2 \mathrm{mM}$ TCEP, $20 \mathrm{mM}$ imidazole $\mathrm{pH}$ 7.5). Protein was eluted (20 mM NaH $\mathrm{PO}_{4}, 250 \mathrm{mM} \mathrm{NaCl}, 1 \mathrm{mM}$ TCEP, $250 \mathrm{mM}$ imidazole, $\mathrm{pH}$ 7.5) and dialyzed into DPBS to remove excess imidazole. The intein was removed through transthioesterification by the addition of sodium mercaptoethanesulfonate (MESNa) a final concentration of $250 \mathrm{mM}$ at $\mathrm{pH} 7$ prior to overnight 
incubation at room temperature. Fragment 1 thioester was finally purified by reversed phase liquid chromatography and pure proteins were characterized by analytical RP-HPLC and mass spectrometry. Purified proteins were freeze-dried prior to storage. Typical yield: $5 \mathrm{mg}$ of fragment (1) per $\mathrm{L}$ of culture.

Generation of HMGB1 Ac ${ }_{3}$ GIcNAc Ser100 Sec94-105 $\mathrm{NHNH}_{2}$ (2). Standard manual Fmoc-based solid phase peptide synthesis were used. 2-chlorotrityl resin (Anaspec) was functionalized with the C-terminal hydrazide according to published protocol ${ }^{1}$. Commercially available N-Fmoc and side-chain- protected amino acids (10 equiv, Advanced ChemTech) were activated for 5 min with HBTU (10 equiv, Novabiochem) and N,Ndiisopropylethylamine (DIEA) (20 equiv) and coupled to the resin for $1 \mathrm{~h}$ with constant agitation. Protected $\mathrm{O}-$ GlcNAcylated serine was prepared as O-pentafluorophenyl (Pfp)-activated esters as previously described ${ }^{2}$ and 2 equivalents were used during coupling without HBTU or DIEA. After each coupling, the resin was washed and the terminal Fmoc group was removed with $20 \% \mathrm{v} / \mathrm{v}$ piperidine in dimethylformamide (DMF) for 15 mins. Deprotection step was repeated by the addition of fresh $20 \%$ piperidine. The final selenocysteine residue was added from a commercially-available para-methoxybenzyl-protected Fmoc amino acid (Chemlmpex) that was also pre-activated and couples as an O-Pfp ester. The final Fmoc group on selenocysteine was removed as described above. Peptides were then cleaved from the resin by the addition of standard cleavage cocktail (95:2.5:2.5 TFA $/ \mathrm{H}_{2} \mathrm{O}$ /triisopropylsilane) supplemented with 1.3 eq of dithiobis(5-nitropyridine) (DTNP, Sigma) for $4 \mathrm{~h}$ at room temperature. The peptides were precipitated in pre-cooled ether and incubated overnight $\left(-80^{\circ} \mathrm{C}\right)$. The peptides were collected by centrifugation $\left(10 \mathrm{~min}, 5000 \mathrm{~g}, 4^{\circ} \mathrm{C}\right.$ ), and resuspended in $50: 50$ acetonitrile: $\mathrm{H}_{2} \mathrm{O}$, flash frozen, and lyophilized. The crude peptide mixture was purified by RP-HPLC (Solvent $A=0.1 \%$ trifluoroacetic acid in $\mathrm{H}_{2} \mathrm{O} ; \mathrm{B}=0.1 \%$ trifluoroacetic acid, $10 \% \mathrm{H}_{2} \mathrm{O}, 90 \%$ acetonitrile) over a C18 semipreparative column (Higgins Analytical). Peptide purity was confirmed by analytical RP-HPLC and characterized by ESI and MALDI-MS. $8 \mathrm{mg}$ of purified fragment (2) was isolated from a $0.1 \mathrm{mmol}$ scale synthesis.

Generation of HMGB1 106-215 (3). BL21(DE3)-pLysS (EMD Millipore) cells were transformed with HMGB1(106-215)-AvaE-6xHis fusion plasmid DNA. Expression and His-tag purification were performed as above for the 1-93 construct. After dialysis of the fusion protein, the intein domain was hydrolyzed by the addition of $250 \mathrm{mM}$ dithiothreitol. The $\mathrm{pH}$ of the solution was adjusted to $>8$ and the mixture was incubated at $37^{\circ} \mathrm{C}$ with rotation for $48 \mathrm{~h}$. The reaction was acidified by the addition of perchloric acid to $5 \% \mathrm{v} / \mathrm{v}$ final concentration. Precipitated protein was removed and the supernatant contained mostly the desired fragment. Methoxylamine was added to $150 \mathrm{mM}$ to deprotect the $\mathrm{N}$-terminal cysteine and the $\mathrm{pH}$ was adjusted to 4 . After $24 \mathrm{~h}$ incubation at room temperature, Fragment 3 was purified by RP-HPLC over a C4 semipreparative column. Peptide purity was confirmed by analytical RP-HPLC and the identity was determined by ESI and MALDI-MS. Typical yield: 1 $\mathrm{mg}$ of fragment (3) per $\mathrm{L}$ of culture.

Ligation and deselenization generating HMGB1 $\mathrm{Ac}_{3}$ GIcNAc Ser100 1-105NHNH $\mathrm{N}_{2}$ (4). Fragment 1 (11 mg, $1.10 \mu \mathrm{mol}, 4 \mathrm{mM}$ final concentration, $1 \mathrm{eq})$ and fragment $2(2 \mathrm{mg}, 1.11 \mu \mathrm{mol}, 4 \mathrm{mM}$ final concentration, $1 \mathrm{eq})$ were dissolved in $250 \mu \mathrm{L}$ of degassed ligation buffer $(6 \mathrm{M}$ guanidine $\mathrm{HCl}, 100 \mathrm{mM}$ phosphate, $100 \mathrm{mM}$ L-ascorbic acid, $50 \mathrm{mM}$ TCEP, $250 \mathrm{mM}$ mercaptophenylacetic acid, pH 7). Reaction was monitored by analytical C4 RPHPLC and ligation product was detected after $1 \mathrm{~h}$. After 16h, the mixture was buffer exchanged 1000-fold into $6 \mathrm{M}$ guanidine $\mathrm{HCl}, 100 \mathrm{mM}$ phosphate $\mathrm{pH} 6$ to remove MPAA. Dithiothreitol was added to a final concentration of $25 \mathrm{mM}$ and the mixture was incubated for $10 \mathrm{mins}$ to fully reduce the selenocysteine residues. Solid TCEP was added to a final concentration of $100 \mathrm{mM}$ and the $\mathrm{pH}$ was adjusted to 5. Analytical RP-HPLC and ESI-MS were used to monitor the conversion of selenocysteine to alanine. After 4 hours, deselenization was deemed complete and fragment 4 was purified by semipreparative RP-HPLC on a C4 column. Purity of the product and identity were confirmed by analytical RP-HPLC and MALDI-MS, respectively. Total isolated yield: $4.15 \mathrm{mg}$.

Ligation and acetate deprotection generating full-length O-GIcNAc Ser100 HMGB1. Fragment 4 (4.15 mg) was dissolved in $110 \mu \mathrm{L}$ of $6 \mathrm{M}$ guanidine $\mathrm{HCl}, 200 \mathrm{mM}$ phosphate, $\mathrm{pH} 3$ buffer and cooled to $-20^{\circ} \mathrm{C}$. To this was added $10 \mu \mathrm{L}$ of $0.5 \mathrm{M} \mathrm{NaNO}_{2}$ solution ( $50 \mathrm{mM}$ final concentration) and the reaction was stirred at this temperature. After 15 mins, $3.2 \mathrm{mg}$ of solid MPAA was added. The $\mathrm{pH}$ was adjusted to 6.5 and the solution was warmed to room temperature. Fragment $3(3 \mathrm{mg})$ in $110 \mathrm{uL} 6 \mathrm{M}$ guanidine $\mathrm{HCl}, 200 \mathrm{mM}$ phosphate, pH 6.5 buffer was added to begin protein ligation. The $\mathrm{pH}$ was carefully adjusted to 7 . At this point, the reaction is $1 \mathrm{mM}$ in each fragment $200 \mathrm{mM}$ in MPAA. Ligation product was detected after 1 hour by analytical RP-HPLC and ESI-MS. Ligation product was purified by semi-preparative HPLC and freeze dried to obtain $3.4 \mathrm{mg}$ of product. To remove the O- 
acetyl protecting groups, this protein was dissolved in $5 \%$ hydrazine monohydrate in $\mathrm{H}_{2} \mathrm{O}$ and incubated for 1 hour at room temperature. The reaction was quenched with $5 \%$ acetic acid, and fully reduced by the addition of solid TCEP before purification over C4 semi-preparative RP-HPLC. Final isolated yield: $1.6 \mathrm{mg}$.

Expression of full-length unmodified HMGB1 and S100A mutant. BL21(DE3)-pLysS (EMD Millipore) cells were transformed with HMGB1(1-215)-AvaE-6xHis fusion plasmid DNA, either wild-type or the S100A mutant. Expression and His-tag purification were performed as above. After dialysis of the fusion protein, the intein domain was hydrolyzed by the addition of $250 \mathrm{mM}$ dithiothreitol. The $\mathrm{pH}$ of the solution was adjusted to $>8$ and the mixture was incubated at $37^{\circ} \mathrm{C}$ with rotation for $48 \mathrm{~h}$. The reaction was acidified by the addition of perchloric acid to $5 \% \mathrm{v} / \mathrm{v}$ final concentration. Precipitated protein was removed and the supernatant contained mostly the desired fragment. Full-length HMGB1 protein was purified by RP-HPLC over C4 semipreparative column. Peptide purity was confirmed by analytical RP-HPLC and the identity was determined by ESI and MALDI-MS. Typical yield: $1 \mathrm{mg}$ of unmodified HMGB1 or $0.5 \mathrm{mg}$ HMGB1(S100A) per L of culture.

Refolding and circular dichroism. Freeze dried HMGB1 or HMGB1(gS100) were refolded by resuspending in $10 \mathrm{mM}$ Tris, $1 \mathrm{mM}$ EDTA, $50 \mathrm{mM} \mathrm{NaCl}, 0.5 \mathrm{mM}$ DTT, pH 7.4. Protein concentrations were determined using $\mathrm{A}_{280}$ absorbance using Abs $0.1 \%(\mathrm{~g} / \mathrm{L})=0.865$ (calculated from sequence), and adjusted to $5 \mathrm{uM}$ with the same buffer. Samples were placed in $1 \mathrm{~mm}$ path length quartz cuvette and far UV spectra (190 nm-250 nm) were obtained by averaging three scans with a $50 \mathrm{~nm} \mathrm{~min}^{-1}$ scanning speed, $1 \mathrm{~nm}$ bandwidth, $1 \mathrm{~nm}$ step size, and data integral speed of $4 \mathrm{sec}$. The blank buffer readings were subtracted for all samples, and the data were converted into mean residue ellipticity.

Topoisomerase I Supercoiling Assay. pUC19 DNA was propagated in E. coli DH5a cells and isolated by standard miniprep techniques (QIAGEN). Indicated amounts of HMGB1 and pUC19 (150 ng) were mixed in low ionic strength buffer (10 mM potassium acetate, $4 \mathrm{mM}$ Tris acetate, $2 \mathrm{mM}$ magnesium acetate, $1 \mathrm{mM}$ DTT, 20 $\mathrm{ug} / \mathrm{mL}$ bovine serum albumin, $\mathrm{pH} \mathrm{7.9)}$ and incubated at room temperature. After $20 \mathrm{mins}, 0.2$ units of $E$. coli Topoisomerase I (NEB) were added and the reaction was incubated at $37^{\circ} \mathrm{C}$ for 1 hour. Reaction was deproteinized with the addition of Proteinase $\mathrm{K}$ to a final concentration of $100 \mu \mathrm{g} / \mathrm{mL}$ and further incubation at $37^{\circ} \mathrm{C}$ for an additional hour. The samples were ran on $1 \%$ agarose gel without any dye at $50 \mathrm{~V}$ for 3 hours. The gel was stained with GelRed (Biotium) according to manufacturer instructions and imaged using ChemiDoc XRS+ Imager (Bio-Rad).

Four-way junction electrophoretic mobility shift assay. Single strand oligonucleotides were ordered from IDT DNA and were based on published sequences known to form cruciforms that HMGB1 binds with high affinity ${ }^{3}$ :

Strand 1: 5' - CCCTATAACCCCTGCATTGAATTCCAGTCTGATAA - 3'

Strand 2: 5' - GTAGTCGTGATAGGTGCAGGGGTTATAGGG - 3'

Strand 3: 5' - AACAGTAGCTGTTATTCGAGCTCGCGCCCTATCACGACTA - 3'

Strand 4: 5' - TTTATCAGACTGGAATTCAAGCGCGAGCTCGAATAACAGCTACTGT - 3'

Four-way junction DNA was prepared by dissolving equimolar amounts of the four strand DNA in annealing buffer (10 mM Tris, $50 \mathrm{mM} \mathrm{NaCl}, 1 \mathrm{mM}$ EDTA, pH 8). The mixture was heated to $95^{\circ} \mathrm{C}$ for 5 mins and slowly cooled to room temperature over 45 mins. Formation of the junction was confirmed by agarose gel electrophoresis. For the gel retardation assay, pre-cast $5 \%$ Tris-borate-EDTA gel (BioRad) was pre-run in 0.5X TBE buffer (Thermo Fisher) for 2 hours on ice. During this time, complexes were formed by combining cruciform DNA (100 nM final concentration) with indicated amounts of HMGB1 or its variants 1X binding buffer (25mM Tris-HCl, $1 \mathrm{mM}$ EDTA, $50 \mathrm{mM} \mathrm{NaCl}, 2 \%$ glycerol, $1 \mathrm{mM}$ DTT, $0.1 \mathrm{mg} / \mathrm{mL}$ bovine serum albumin). Protein-DNA complexes (10 uL total volume) were incubated on ice for 30 mins, after which $2 \mathrm{uL}$ of $6 \mathrm{X}$ native gel loading dye (NEB). Complexes were separated by running the gel at $100 \mathrm{~V}$ for 1.5 hours on ice. After electrophoresis, the gel was stained with GelRed and imaged. For densitometry quantifications, ImageLab (Biorad) software was used for band quantification of bound and unbound fraction of DNA. Data analysis was performed using GraphPad Prism 8 using nonlinear regression fitting of saturation binding. 
Expression and purification of recombinant histones. Histones were expressed and purified as described in Kilic et al. ${ }^{4}$. Briefly, individual wild-type human histones were cloned into pet15b plasmid vectors and expressed in BL21 DE3 plysS cells. Cells were grown in LB media containing $100 \mu \mathrm{g} / \mathrm{mL}$ ampicillin and $35 \mu \mathrm{g} / \mathrm{mL}$ chloramphenicol at $37^{\circ} \mathrm{C}$ until the OD600 reached 0.6. Expression was induced by IPTG addition to a final concentration of $0.5 \mathrm{mM}$. After $3 \mathrm{~h}$ expression, cells were harvested by centrifugation and resuspended in lysis buffer (20 mM Tris pH 7.5, $1 \mathrm{mM}$ EDTA, $200 \mathrm{mM} \mathrm{NaCl}, 1 \mathrm{mM} \beta M e$, Roche protease inhibitor) and frozen. Cells were lysed by freeze-thawing and sonication. Inclusion bodies were harvested by centrifugation. The inclusion body pellet was washed once with $7.5 \mathrm{~mL}$ of lysis buffer containing $1 \%$ Triton and once without. Inclusion body pellets were resolubilized in resolubilization buffer $(6 \mathrm{M} \mathrm{GdmCl}, 20 \mathrm{mM}$ Tris $\mathrm{pH} 7.5,1 \mathrm{mM}$ EDTA, $1 \mathrm{mM} \beta M$ ) and dialyzed into urea buffer (7 M urea, $10 \mathrm{mM}$ Tris, $1 \mathrm{mM}$ EDTA, $0.1 \mathrm{M} \mathrm{NaCl}, 5 \mathrm{mM} 1 \mathrm{mM} \beta M e, p H ~ 7.5)$. Histones were purified by cation exchange chromatography using a HiTrap SP HP $5 \mathrm{~mL}$ column (GE Healthcare). Fractions were analyzed by SDS-PAGE and pooled, followed by dialysis into water and lyophilization. Final purification was performed by preparative RP-HPLC. Purified histones were lyophilized and stored at $-20^{\circ} \mathrm{C}$ until used for octamer refolding.

Mononucleosome (MN) nucleosome formation. Nucleosomes were prepared following Dyer et al. ${ }^{5}$. Typically, $1-5 \mu \mathrm{g}$ of $147 \mathrm{bp}$ or $218 \mathrm{bp} 601$ DNA was combined with purified refolded octamers at experimentally determined ratios (1:1 to 1:2, DNA to histone octamer) in $30 \mu \mathrm{TE}(10 \mathrm{mM}$ Tris-HCl pH 7.5, $1 \mathrm{mM}$ EDTA) supplemented with $2 \mathrm{M} \mathrm{KCl}$. These were added to a micro-dialysis unit (Thermo Scientific, Slide-A-Lyzer - 10,000 MWCO), then dialyzed in TE buffer (10 mM Tris pH 7.5, $0.1 \mathrm{mM}$ EDTA pH 8.0) with a linear gradient from $2 \mathrm{M}$ to $10 \mathrm{mM} \mathrm{KCl}$ for 16-18 h, and finally kept in TEK10 buffer (10 mM Tris pH 7.5, 0.1 mM EDTA pH 8.0, $10 \mathrm{mM} \mathrm{KCl)} \mathrm{for} \mathrm{another}$ $1 \mathrm{~h}$. Samples were then spun at $20^{\prime} 000 \times \mathrm{g}$ for $10 \mathrm{~min}$ at $4^{\circ} \mathrm{C}$ and the supernatant was kept on ice. To determine the quality of MN assemblies, $0.6 \%$ Agarose $0.25 \times$ TB gels were run at $90 \mathrm{~V}$ on ice for $90 \mathrm{~min}$.

Nucleosome electrophoretic mobility shift assays. EMSAs to determine HMGB1 or HMGB1(gS100) binding to DNA were done in EMSA buffer $(20 \mathrm{mM}$ Tris- $\mathrm{HCl}, 100 \mathrm{mM} \mathrm{KCl}, 1 \mathrm{mM}$ DTT), with $10 \mu \mathrm{L}$ total volume. Typically, $800 \mathrm{nM}$ stocks of DNA or nucleosomes were mixed with HMGB1 or HMGB1(gS100) to a final concentration of $\sim 50 \mathrm{nM}$ DNA/nucleosome and indicated protein concentration. Reactions were mixed by pipetting and left for 30 min on icee. Sucrose was added to a final concentration of $5 \%$ and reactions were loaded onto $5 \%$ Polyacrylamide gels run in $0.25 \times$ TBE at $100 \mathrm{~V}$ for $60 \mathrm{~min}$. Images were taken using ChemiDoc MP (Biorad).

$218 \mathrm{bp}-601$ sequence:

ATTCGCACACTGTGCCAAGTACTTACTCGTGCGCCCTGGAGAATCCCGGTGCCGAGGCCGCTCAATTGG TCGTAGACAGCTCTAGCACCGCTTAAACGCACGTACGCGCTGTCCCCCGCGTTTTAACCGCCAAGGGGA TTACTCCCTAGTCTCCAGGCACGTGTCAGATACTGCAGAGATCTCACGAGCCATGGAGTACTTGGTCTCA AACCGCAAGCT

$147 \mathrm{bp}-601$ sequence

GCTGGAGAATCCCGGTGCCGAGGCCGCTCAATTGGTCGTAGACAGCTCTAGCACCGCTTAAACGCACGT ACGCGCTGTCCCCCGCGTTTTAACCGCCAAGGGGATTACTCCCTAGTCTCCAGGCACGTGTCAGATATAT ACATCCTGTCG

DNA circularization assay. A pcDNA3 vector was modified to contain a 123bp segment flanked by 5' and 3' $\mathrm{Kpnl}$ digestion sites. After propagation in $\mathrm{DH} 5 \mathrm{a}$ and isolation by miniprep, the plasmid was digested with $\mathrm{Kpnl}$ enzyme (NEB) and the $123 \mathrm{bp}$ fragment was gel purified. This fragment was further amplified by PCR (KOD Hotstart, EMD Millipore), Kpnl digested, gel purified, and ethanol precipitated to concentrate the DNA. $100 \mathrm{ng}$ of this DNA was mixed with indicated amounts of HMGB1 in 1X T4 DNA ligase buffer (10X stock from NEB; 1X final concentrations: $50 \mathrm{mM}$ Tris- $\mathrm{HCl}, 10 \mathrm{mM} \mathrm{MgCl}, 0.1 \mathrm{mM}$ ATP, $1 \mathrm{mM}$ DTT, pH 7.5). After complex formation on ice for 20 minutes, 2 units of T4 DNA ligase (NEB) was added per experiment and incubated at room temperature for 1 hour. The enzyme was heat inactivated at $65^{\circ} \mathrm{C}$ for 20 mins. 20 units of Exonuclease II (NEB) were added per reaction. After incubation at $37^{\circ} \mathrm{C}$ for $30 \mathrm{mins}$, the reactions were deproteinized with Proteinase $\mathrm{K}\left(100 \mu \mathrm{g} / \mathrm{mL}\right.$ final concentration) at $37^{\circ} \mathrm{C}$ for 1 hour. DNA samples were ran on $2 \%$ agarose gels (cast without ethidium bromide) at $100 \mathrm{~V}$ for 1 hour. Gels were stained with GelRed and imaged accordingly. Densitometric quantitation were performed using a ChemiDoc XRS+ Imager with the BioRad Image Lab software. Signal volumes were normalized to the maximum signal for each experiment and reported as \%Maximum minicircles 
in Figure S5a. Nonlinear regression fitting of saturation binding with Hill coefficient was performed using GraphPad Prism 8.

\section{Triplex-directed ICL formation}

Triplex forming oligonucleotide (TFO)-directed site specific interstrand cross links on 57 base pair duplex substrates were prepared as we have described previously ${ }^{6}$. Briefly, triplex substrates were formed by incubating radiolabeled 57 bp duplexes $\left(10^{-6} \mathrm{M}\right)$ with psoralen-conjugated 30 mer TFOs $\left(10^{-6} \mathrm{M}\right)$ in a triplex binding buffer [10 mM Tris- $\mathrm{HCl}, \mathrm{pH} 7.6,10 \mathrm{mM} \mathrm{MgCl}$, and $10 \%$ (vol/vol) glycerol] at $37^{\circ} \mathrm{C}$ for $16 \mathrm{~h}$. Samples were irradiated with $1.8 \mathrm{~J} / \mathrm{cm}^{2}$ of UVA $(365 \mathrm{~nm})$ to form psoralen ICLs. The efficiency of triplex-ICL formation was assessed at $\sim 50 \%$.

\section{DNA-protein binding assays}

To assess DNA-protein complex formation, $10^{-9} \mathrm{M}$ DNA substrate was incubated with indicated amounts of HMGB1, HMGB1(gS100) or HMGB1(S100A) proteins separately in DNA binding buffer (25 mM Tris- $\mathrm{HCl} \mathrm{pH} 7.6$, $100 \mathrm{mM} \mathrm{NaCl}, 1 \mathrm{mM}$ DTT, $5 \mathrm{mM}$ EDTA, $100 \mu \mathrm{g} / \mathrm{mL}$ BSA, $0.01 \%$ Nonidet P-40, and 10\% glycerol) in a $10 \mu \mathrm{l}$ reaction volume. Reactions were subsequently incubated for 20 minutes at $30^{\circ} \mathrm{C}$. The DNA-protein complexes were then resolved on $6 \%$ native polyacrylamide (acrylamide:bis acrylamide $=37.5: 1)$ gels in $1 \times$ TBE $(89 \mathrm{mM}$ Tris-borate, $\mathrm{pH}$ 8.0, 2 mM EDTA) buffer for 2 hours at $4^{\circ} \mathrm{C}$. Subsequently, gels were dried, exposed overnight and visualized using a phosphorimager.

siRNA transfection and Mutagenesis assay. Triplex forming oligonucleotide (TFO) AG30 was synthesized and HPLC purified by Midland Certified Reagent Co. (Midland, TX) as previously described ${ }^{7}$. The triplex-directed ICL containing pSupFG1 reporter plasmid was prepared and purified as previously described ${ }^{8}$. siRNA transfection was performed as described before ${ }^{8}$. Briefly, HMGB1 depleted whole cell extract was prepared by reverse transfection of HMGB1 siRNA (Dharmacon, Lafayette, CO) into human osteosarcoma U2OS cells with RNAiMAX (ThermoFisher, Waltham, MA) as per manufacturer recommended protocol. Twenty-four hours later a second round of transfection was performed (forward transfection). Forty-eight hours later after the second transfection, cells were collected and extracts were prepared using the NE-PER Nuclear and Cytoplasmic Extraction Reagent Kit (ThermoFisher, Waltham, MA) following manufacturer recommended protocol. Depletion of HMGB1 in the extract was assessed by immunoblot as described before ${ }^{8}$. Concentration of HMGB1 in wild type U2OS extract was determined by creating a standard curve from immunoblot and similar levels of recombinant HMGB1, O-GIcNAc-modified HMGB1 and S100A-HMGB1 were added to the HMGB1 depleted extract for mutagenesis assays.

Mutagenesis assays were performed as described before ${ }^{7}$. To determine the effect of O-GlcNAc modification of HMGB1 and the S100A mutant compared to HMGB1 in the processing of ICL-induced or UVC-induced DNA lesions, $300 \mathrm{ng}$ of untreated pSupFG1 plasmid $(\mathrm{P})$ and TFO-directed ICL-induced pSupFG1 (P-ICL) were separately incubated in $125 \mu \mathrm{g}$ of whole cell extract in $60 \mathrm{mM} \mathrm{KCl}, 7.5 \mathrm{mM} \mathrm{MgCl}, 0.9 \mathrm{mM}$ DTT, $0.4 \mathrm{mM}$ EDTA, $2 \mathrm{mM}$ ATP, $20 \mu \mathrm{M}$ each of dGTP, dCTP, dTTP and $8 \mu \mathrm{M}$ dATP, $40 \mathrm{mM}$ phosphocreatine, $2.5 \mu \mathrm{g}$ creatine phosphokinase (Type I, Sigma), 3.4\% glycerol and $18 \mu \mathrm{g}$ BSA. The HMGB1 depleted extracts were separately supplemented with recombinant HMGB1, HMGB1(gS100), or HMGB1(S100A). Wild type U2OS extract was used as a positive control. Plasmids were incubated for 4 hours at $37^{\circ} \mathrm{C}$ in the extracts. Reactions were terminated by adding $2 \mu \mathrm{L}$ of proteinase $\mathrm{K}(20 \mathrm{mg} / \mathrm{mL})$ and $4 \mu \mathrm{L}$ of $20 \%$ SDS per reaction and incubated for 4 hours at $65^{\circ} \mathrm{C}$. Plasmids were then purified by phenol:chloroform:isoamyl alcohol extraction and ethanol precipitation with $0.3 \mathrm{M}$ sodium acetate $(\mathrm{pH} 5.2)$. Subsequently, the DNA was resuspended in $20 \mu \mathrm{L}$ nucleasefree water. To remove the non-replicated plasmids and asses complete processing, the plasmids were further treated with $2 \mu \mathrm{L}$ Dpnl restriction endonuclease (BIO-RAD, Hercules, CA) for 2 hours at $37^{\circ} \mathrm{C}$ followed by another round of phenol:chloroform:isoamyl alcohol extraction and ethanol precipitation. Subsequently, the DNA samples were resuspended in $20 \mu \mathrm{L}$ nuclease-free water and transformations were performed immediately. Mutations generated as a result of DNA damage processing were identified by transforming $30 \mu \mathrm{L} E$. coli MBM7070 electrocompetent cells (Lucigen, Middleton, WI) with $2 \mu \mathrm{l}$ of the resuspended DNA followed by plating on XGAL, ampicillin and IPTG plates for blue/white screening. Sixteen hours post transformation, plates were collected and colonies were counted. A blue colony represents a functional SupF gene and a white colony represents a mutated SupF gene. Mutation frequencies were determined by dividing the total number of mutated white colonies by the total number of colonies. Three individual experiments were performed for each of the samples 
and $>20,000$ colonies were counted per experiment. Mutation spectra was determined by isolating the mutated plasmids and direct sequencing of the plasmids.

\section{References}

(1) Zheng, J.-S.; Tang, S.; Qi, Y.-K.; Wang, Z.-P.; Liu, L. Chemical Synthesis of Proteins Using Peptide Hydrazides as Thioester Surrogates. Nat. Protoc. 2013, 8 (12), 2483-2495. https://doi.org/10.1038/nprot.2013.152.

(2) De Leon, C. A.; Lang, G.; Saavedra, M. I.; Pratt, M. R. Simple and Efficient Preparation of O- and S-

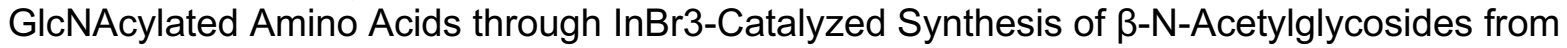
Commercially Available Reagents. Org. Lett. 2018, 20 (16), 5032-5035. https://doi.org/10.1021/acs.orglett.8b02182.

(3) Bianchi, M. E.; Beltrame, M.; Paonessa, G. Specific Recognition of Cruciform DNA by Nuclear Protein HMG1. Science (80-. ). 1989, 243 (4894), 1056-1059.

(4) Kilic, S.; Bachmann, A. L.; Bryan, L. C.; Fierz, B. Multivalency Governs HP1a Association Dynamics with the Silent Chromatin State. Nat. Commun. 2015, 6, 7313. https://doi.org/10.1038/ncomms8313.

(5) Dyer, P. N.; Edayathumangalam, R. S.; White, C. L.; Bao, Y.; Chakravarthy, S.; Muthurajan, U. M.; Luger, K. B. T.-M. in E. Reconstitution of Nucleosome Core Particles from Recombinant Histones and DNA. In Chromatin and Chromatin Remodeling Enzymes, Part A; Academic Press, 2003; Vol. 375, pp 23-44. https://doi.org/https://doi.org/10.1016/S0076-6879(03)75002-2.

(6) Reddy, M. C.; Christensen, J.; Vasquez, K. M. Interplay between Human High Mobility Group Protein 1 and Replication Protein A on Psoralen-Cross-Linked DNA. Biochemistry 2005, 44 (11), 4188-4195. https://doi.org/10.1021/bi047902n.

(7) Christensen, L. A.; Conti, C. J.; Fischer, S. M.; Vasquez, K. M. Mutation Frequencies in Murine Keratinocytes as a Function of Carcinogenic Status. Mol. Carcinog. 2004, 133 (November 2003), 122133. https://doi.org/10.1002/mc.20026.

(8) Mukherjee, A.; Vasquez, K. M. HMGB1 Interacts with XPA to Facilitate the Processing of DNA Interstrand Crosslinks in Human Cells. Nucleic Acids Res. 2016, 44 (3), 1151-1160. https://doi.org/10.1093/nar/gkv1183. 